\title{
Immunocytochemical Characterization of Explant Cultures of Human Prostatic Stromal Cells
}

\author{
Anko Kooistra, Nancy M.J. Elissen, Josée J. König, Marcel Vermey, \\ Theodorus H. van der Kwast, Johan C. Romijn, and Fritz H. Schröder \\ Departments of Urology (A.K., N.M.J.E., J.J.K., J.C.R., F.H.S.) and Pathology (M.V., \\ T.H.v.d.K.), Erasmus University, Academic Hospital Dijkzigt, Rotterdam, The Netherlands
}

\begin{abstract}
The study of stromal-epithelial interactions greatly depends on the ability to culture both cell types separately, in order to permit analysis of their interactions under defined conditions in reconstitution experiments. Here we report the establishment of explant cultures of human prostatic stromal cells and their immunocytochemical characterization. As determined by antibodies to keratin and prostate specific acid phosphatase, only small numbers $(<5 \%)$ of epithelial cells were present in primary cultures; subsequent passaging further reduced epithelial cell contamination. Antibodies against intermediate filament proteins (keratins, vimentin, and desmin) and smooth muscle actin microfilaments demonstrated that stromal cells from benign prostatic hyperplasia and prostate carcinoma differed in regard to their differentiation markers. Two contrasting phenotypes were identified in cultures derived from these two different lesions: One, exhibiting fibroblastic features, was predominant in cultures derived from benign lesions and a second, showing varying degrees of smooth muscle differentiation, was more abundant in carcinoma-derived cultures. These findings are indicative of a remarkable divergence in the stromal-epithelial relationships associated with these pathological conditions and may provide us with a potential tool for studying these processes. 1995 Wiley-Liss, Inc.
\end{abstract}

KEY WORDS: immunocytochemistry, intermediate filament proteins, human prostatic stromal cells, fibroblasts, prostatic cancer, benign prostatic hyperplasia

\section{INTRODUCTION}

Control of cellular proliferation in the prostate involves a complex interaction of different cell types with soluble peptide growth factors, (steroid) hormones, and constituents of the extracellular matrix. The central role of urogenital sinus mesenchyme in prostatic ductal morphogenesis, epithelial growth, secretory cytodifferentiation, and function has been clearly demonstrated. All these androgen-induced effects were shown to be mediated by mesenchyme in the perinatal period [1]. Further studies on tissue recombinants indicated that stromal-epithelial interactions have retained their integral role in the adult gland [2]. For example, although the androgen receptor is expressed in prostate epithelium, it is believed that the proliferative effect of androgen on epithelium in the adult gland is also mediated by the stroma $[3,4]$.
Detailed studies require the capability to culture epithelial and stromal cells separately in order to permit reconstitution and analysis of their interactions under defined conditions. There have been several reports concerning primary culture of murine prostate epithelial [3] and stromal cells [4-7], while less information is available on in vitro models derived from human tissue. Although several human prostatic carcinoma cell lines have become available during the past decade [8-11], and methods were developed for primary culture of epithelial cells from normal and diseased prostates [12-16], only a few

Received for publication April 19, 1994; accepted August 24, 1994. Address reprint requests to Anko Kooistra, Department of Urology, Erasmus University, Academic Hospital Dijkzigt, P.O. Box 1738, 3000 DR Rotterdam, The Netherlands. 
papers have been published of studies using cultured human prostatic stromal cells. No studies have been conducted so far regarding the characterization of these cells, which were tentatively designated as fibroblasts, a nomenclature mainly based on cell morphology.

Analysis of cytoskeletal proteins is commonly used to assess the differentiation state and embryonic derivation of many cell types [17-20]. The availability of antibodies against the intermediate-sized filament proteins keratin, vimentin, and desmin has made it possible to distinguish between cells with epithelial, mesenchymal, and myogenic differentiation [18-22]. Further characterization of stromal cells can be achieved by analysis of actin isoform expression $[23,24]$. These developments have recently led to the recognition of a phenotypic heterogeneity among fibroblasts, which might be related to different biologic behaviors [24]. Fibroblastic cells have been found to express a repertoire of muscle differentiation features in physiologic as well as in pathologic conditions [24]. Many human epithelial tumors, for instance, are associated with the appearance of these so-called myofibroblasts that are believed to be responsible for the frequent, excessive collagen deposition and tissue contraction referred to as desmoplasia [25].

In this paper we describe the immunocytochemical characterization of explant cultures of human prostatic stromal cells. The presence of residual epithelial cells in these cultures was determined using antibodies to keratin and prostate specific acid phosphatase. Subsequently, antibodies against other intermediate filament proteins and microfilament smooth muscle actin were used to investigate stromal cell cultures derived from benign prostatic hyperplasia $(\mathrm{BPH})$ and prostate carcinoma (PC) in order to reveal possible phenotypic differences. Several cultures were tested at subsequent passages in order to monitor potential shifts in the expression of these markers during the course of subculturing.

\section{MATERIALS AND METHODS}

\section{Human Prostate Tissues}

Wedges of human prostate tissue were dissected from benign hyperplastic nodules and prostate cancers obtained by open prostatectomy or transurethral resection. After removal of portions of tissue for culture, the remaining prostate was fixed in formal dehyde and serially sectioned. The histology of hematoxylin- and eosin-stained sections immediately adjacent to tissue removed for culture was reviewed, and the findings were correlated with the findings in the corresponding cultures. All six prostatic malig- nancies were moderately differentiated adenocarcinomas, except for PC 302 and PC 313, which were both poorly differentiated carcinomas. Benign prostatic hyperplasia (BPH) tissue explants showed glandular hyperplasia in all seven explants, while in samples PA 557 and PA 558 an additional fibromuscular hyperplasia was noted.

\section{Tissue Explants and Subcultures}

Tissue specimens were cut into small pieces of approximately $2 \times 2 \mathrm{~mm}$ and placed in $60 \mathrm{~mm}$ petri dishes (Nunc) containing Earle's minimum essential medium (Gibco Europe, Breda, Netherlands) supplemented with $10 \%$ fetal calf serum (Hyclone Laboratories, Logan, Ut), $2 \mathrm{mM}$ glutamine, penicillin (100 $\mathrm{U} / \mathrm{ml}$ ), and streptomycin $(0.1 \mathrm{mg} / \mathrm{ml}$ ) (all from Gibco Europe). Cultures were maintained in a humidified incubator at $37^{\circ} \mathrm{C}$ in $5 \% \quad \mathrm{CO}_{2}$ /air. Medium was replaced twice a week. For subculture, cells were detached by trypsinization $(0.05 \%$ containing $0.02 \%$ EDTA; Gibco) and split in a 1:3 ratio as soon as monolayers became confluent.

\section{Immunostaining Procedures}

Cytospins of cultures were prepared after trypsinization. Following the preparation of a single cell suspension in culture medium, cells were washed and resuspended in phosphate buffered saline (PBS) at a final concentration of $10^{5}$ cells $/ \mathrm{ml}$. Subsequently, $0.1 \mathrm{ml}$ of this suspension was spun down in a cytospin centrifuge for $10 \mathrm{~min}$ at $150 \mathrm{~g}$. Cytospin preparations were dried in air, fixed in cold acetone $\left(-20^{\circ} \mathrm{C}\right)$ for $10 \mathrm{~min}$, and left to dry at room temperature. In order to preserve cell morphology during the procedure, some of the stromal cell strains were seeded on object slides and stained in situ after 2-3 days of culture. Cytospins and fixed cell preparations were stored at $-20^{\circ} \mathrm{C}$ until further use. As a control, skin fibroblasts (passage number 11-12) were treated similarly. Acetone-fixed BPH tissue sections were taken as positive controls for the applied antibodies.

The staining procedure included preincubation with blocking serum to reduce nonspecific staining. Nonimmune swine serum (DAKO, Denmark) was used for polyclonal antibodies, and nonimmune rabbit serum (DAKO) was used for monoclonal antibodies. Both sera were diluted 10 times in PBS before use. Object slides were then incubated with the specified antibody (Table I) for $30 \mathrm{~min}$ at $37^{\circ} \mathrm{C}$ at the indicated dilution. We used rabbit anti-mouse peroxidase (DAKO) as secondary antibodies, diluted 1/100 and containing $2 \%$ nonimmune rabbit serum and swine anti-rabbit peroxidase (DAKO), diluted 1/100, for 
TABLE I. Antibodies Used

\begin{tabular}{|c|c|c|c|c|}
\hline Antibody & Antigen [ref.] & Source & Dilution & Supplier \\
\hline NCL-5D3 & $\begin{array}{l}\text { Keratins } 8,18 \& 19 \\
\quad \text { acinary epithelium [26] }\end{array}$ & Mouse $^{a}$ & $1 / 10$ & Euro-Diagnostica (Apeldoorn, NL) \\
\hline RGE53 & $\begin{array}{l}\text { Keratin } 18 \\
\quad \text { luminal cells [17] }\end{array}$ & Mouse $^{a}$ & $1 / 10$ & Euro-Diagnostica \\
\hline RKSE60 & $\begin{array}{l}\text { Keratin } 10 \\
\quad \text { squamous epithelium [21] }\end{array}$ & Mouse $^{\mathrm{a}}$ & $1 / 10$ & Euro-Diagnostica \\
\hline RCK103 & $\begin{array}{l}\text { Keratin } 5 \\
\quad \text { basal cells [27] }\end{array}$ & Mouse $^{a}$ & $1 / 5$ & $\begin{array}{l}\text { Dr. F.C.S. Ramaekers, Dept. of Pathology, } \\
\text { University of Maastricht (Maastricht, NL) }\end{array}$ \\
\hline$\alpha$-PSAP & $\begin{array}{l}\text { Prostate specific acid phosphatase } \\
\text { prostatic glandular epithelium [28] }\end{array}$ & Rabbit $^{b}$ & $1 / 1,000$ & $\begin{array}{l}\text { Dept. of Pathology, Erasmus University } \\
\text { (Rotterdam, NL) }\end{array}$ \\
\hline $\mathrm{F} 39.4$ & Androgen receptor [29] & Mouse $^{\mathrm{a}}$ & $1 / 10,000$ & Dept. of Pathology, Erasmus University \\
\hline $1 \mathrm{~A} 4$ & $\begin{array}{l}\alpha \text {-smooth muscle actin } \\
\text { smooth muscle cells [23] }\end{array}$ & Mouse $^{a}$ & $1 / 60,000$ & Sigma (St Louis, MO) \\
\hline Mon-3001-5 & $\begin{array}{l}\text { Desmin } \\
\text { muscle cells [supplier] }\end{array}$ & Mouse $^{a}$ & $1 / 15$ & Sanbio (Uden, NL) \\
\hline PVI & Vimentin [30] & Rabbit $^{b}$ & $1 / 15$ & Euro-Diagnostica \\
\hline
\end{tabular}

${ }^{a}$ Monoclonal antibody.

bPolyclonal antibody.

monoclonal and polyclonal antibodies, respectively. All dilutions of sera or antibodies were prepared with PBS ( $\mathrm{pH} 7.2$ ), except for polyclonal antibodies, which were diluted in PBS containing 5\% bovine serum albumin (BSA). The peroxidase activity was visualized by $\mathrm{DAB}$ and hydrogen peroxide. All samples were counterstained with Mayer's hematoxylin.

\section{Cell Counts}

Scoring of positively stained cells was done by one investigator, at $100 \times$ magnification. At least 500 cells were counted per sample. Differences between groups were considered statistically significant if a $P$ value $\leq 0.05$ was found using the Wilcoxon rank test (Mann-Whitney).

\section{RESULTS}

Explant cultures of prostatic tissue gave rise to an initial halo of epithelial cells within a few days. After approximately 1 week, the first strands of fibroblastic cells could be seen growing out of the tissue blocks. During the following weeks, epithelial cells became increasingly overgrown by stromal cells. Subculturing after trypsinization appeared to promote stromal cell growth and to reduce epithelial cell contamination. At low density the stromal cells had a flattened, irregular polygonal appearance, while at confluent culture they showed a more spindlelike morphology and formed dense aggregates of elongated cells into fan-shaped bundles (Fig. 1). No morphological differences were observed between cultures derived from malignant and nonmalignant lesions. Doubling times of the established stromal cell strains varied between 2 and 4 days.

In order to assess the extent of epithelial contamination of stromal cell cultures, epithelium-specific antibodies were applied to cytospin preparations and to cultures grown on glass slides. After three or more passages, prostate specific acid phosphatase, a marker of glandular epithelium known to be expressed in vitro [16], was not detectable in our cultures (Table II). Similarly, no androgen receptor (AR)positive cells were detected, even though in $\mathrm{BPH}$ tissue sections some of the stromal cell nuclei reacted with the AR-specific antibody (not shown). Since epithelial cells are known to express keratins as well during in vitro culture, keratin antibodies have been used to evaluate prostatic epithelial cell cultures derived from human tissues $[15,16]$. To confirm that the ratio of epithelial/stromal cells shifts in favor of the stromal cells with increasing culture time, primary cultures were harvested after 1 week when the initial outgrowth of solely epithelial-like cells was seen (PA 555 = positive control), other cultures were trypsinized after several weeks, giving the fibroblasts enough time to crowd out the epithelial cells (PA 544, PA 546, PC 302, PC 303 = negative controls). The remaining cultures shown in Figure 2 were trypsinized after an intermediate period of time; both fibroblasts and epithelial cells were recognized by phase contrast microscopy. Cytospins prepared from the cultures were stained with the NCL-5D3 antibody, which is specific for keratins of glandular epi- 


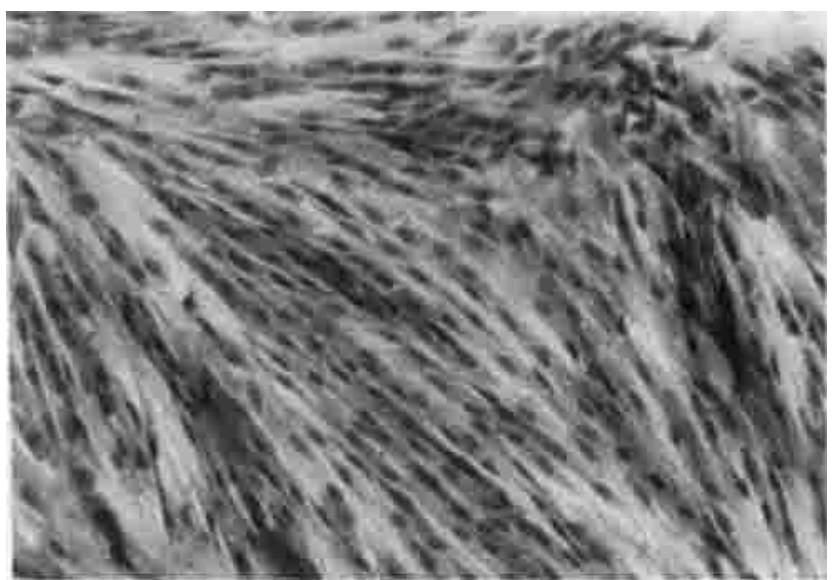

Fig. I. Stromal cell culture derived from malignant prostatic tissue (fifth passage). Giemsa staining, magnification $100 \times$.

thelium. As a result, only a small fraction $(1.0-4.2 \%)$ of the cells from long-term primary cultures showed a positive reaction with the NCL-5D3 antibody, whereas in early stage PA 555 (positive control) more than $98 \%$ of the cells were keratin positive (Fig. 2). Primary cultures that were scored after 2-3 weeks showed intermediate levels of epithelial cell contamination. However, at subculture the epithelial cell number rapidly decreased, as illustrated by culture PC 313 in Figure 3. To exclude the possibility that epithelial cells had escaped identification due to a change in chain-specific cytokeratin expression during in vitro growth, other keratin-specific antibodies were applied as well. As no staining was detected with these antibodies (Table II), it became unlikely that morphologically atypical basal cells reactive with RCK103 or cells with squamous metaplasia reactive with RKSE60 were present.

All six stromal cell strains tested, as well as control cultures of skin fibroblasts, were strongly stained by vimentin antibody (Table II). Cytospin preparations of four more carcinoma-derived and four BPH-derived cultures also contained over $95 \%$ vimentin-positive cells. Cytospins of the keratin-positive epithelial outgrowth of explant PA 555, however, showed similar numbers of cells reacting with vimentin antibodies.

Using cells cultured on glass slides, desmin antibodies stained a fine network of mainly longitudinally running filaments covering the entire cytoplasm in all cell strains (Fig. 4). In cytospin preparations, the average number of desmin-containing cells was estimated to be $21.5 \%$ (median 17.9; S.D. 19.7) for carcinoma- and $4.6 \%$ (median 1.4; S.D. 7.7) for BPHderived cultures (Fig. 2). This difference in desminpositive cells proved to be statistically significant $(P \leq$
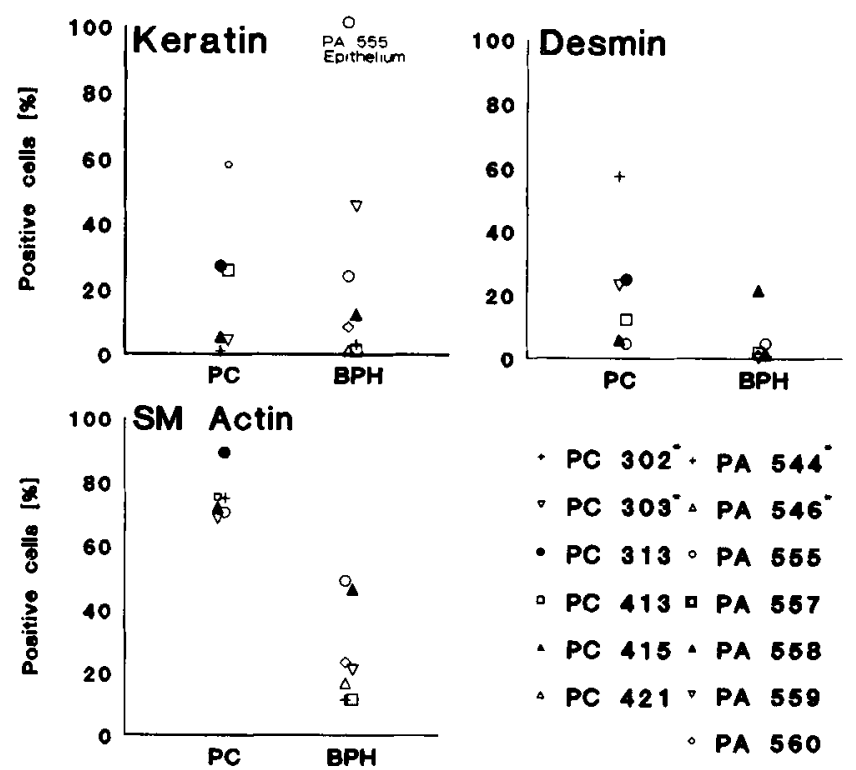

Fig. 2. Immunocytochemical detection of keratins (NCL-5D3 antibody), desmin, and $\alpha$-smooth muscle actin in cytospins prepared from the first outgrowth (passage \#I) of stromal cells from malignant (PC) and benign (BPH) prostatic tissue specimens in explant culture. *Left to crowd out epithelial cells. Desmin content $\mathrm{PC}>$ $\mathrm{BPH}: P \leq 0.05$ and $\alpha-\mathrm{SM}$ actin content $\mathrm{PC}>\mathrm{BPH}: P \leq 0.01$ (Wilcoxon rank test, $n=13$ ).


Paceege or


$-\bullet-$ PC 313

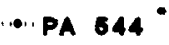

- PA $846^{\circ}$

Fig. 3. Expression of keratin, desmin, and $\alpha$-smooth muscle actin in stromal cell cultures at subsequent passages of in vitro culture. * Left to crowd out epithelial cells.

0.05) using the Wicoxon rank test. The percentage of positively stained cells was relatively constant over several passages (Fig. 3). To this end, cell strains were maintained in culture up to 6 months. 
TABLE II. Immunocytochemical Analyses of Prostatic Stromal Cells Cultured and Fixed on Object Slides

\begin{tabular}{|c|c|c|c|c|}
\hline \multirow[b]{2}{*}{ Antibody } & & \multicolumn{2}{|c|}{ Control } & \multirow[b]{2}{*}{ Stromal cell cultures } \\
\hline & & $\begin{array}{c}\mathrm{BPH} \\
\text { tissue }\end{array}$ & $\begin{array}{l}\text { Skin } \\
\text { fibroblasts }^{\mathrm{b}}\end{array}$ & \\
\hline \multicolumn{5}{|c|}{ A: Epithelial markers } \\
\hline NCL-5D3 & Acinary epithelium & $+^{\mathrm{c}}$ & - & - \\
\hline RGE53 & Luminal cells & $+^{c}$ & - & - \\
\hline RKSE60 & Squamous epithelium & - & - & - \\
\hline RCK103 & Basal cells & $+^{d}$ & - & - \\
\hline$\alpha$-PSAP & Prostate specific acid phosphatase & $+^{c}$ & - & - \\
\hline F39.4 & Androgen receptor & $+c, e$ & - & - \\
\hline \multicolumn{5}{|c|}{ B: Stromal markers } \\
\hline $1 \mathrm{~A} 4$ & $\alpha$-smooth muscle actin & $++^{e}$ & - & + \\
\hline Mon-3001-5 & Desmin & $+{ }^{e}$ & - & + \\
\hline PVI & Vimentin & $+{ }^{e}$ & + & + \\
\hline
\end{tabular}

"At least four different cell "strains" were tested at passages \#2-8.

bassage number 11-12.

'Glandular epithelium.

${ }^{\mathrm{d}}$ Basal cells.

eStroma.
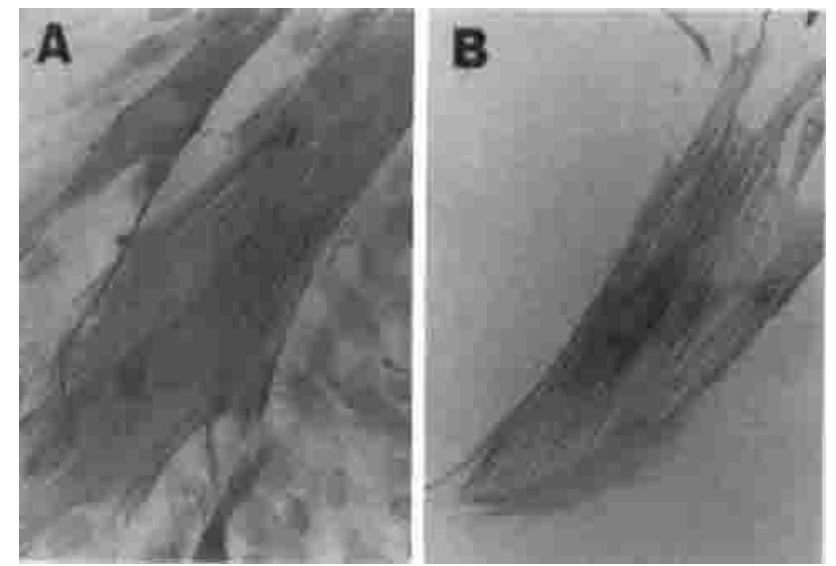

Fig. 4. Immunocytochemical staining of desmin (A) and $\alpha$ smooth muscle actin (B) in prostatic stromal cells cultured on object slides at low density. Magnification $400 \times$.

The 1A4 antibody, directed against $\alpha$-smooth muscle (SM) actin, stained more coarse longitudinal fibrillar structures in the cytoplasm (Fig. 4). In primary cultures, the average number of positive cells in carcinoma-derived cultures (mean 75\%; median 73.6; S.D. 7.4) was significantly larger $(P \leq 0.01)$ than the number in BPH-derived stromal cell cultures (mean 25.6\%; median 21.0; S.D. 15.8). These differences, however, were only manifest during early passages. At higher passage numbers, the percentage of $\alpha$-SM actin-positive cells in BPH-derived stromal cell cultures increased, whereas in carcinoma-derived cul- tures the number of positive cells generally declined (Fig. 3).

\section{DISCUSSION}

The results presented in this paper show the relative ease with which stromal cell cultures can be obtained from prostatic tissue explants. After a few weeks, the rich culture medium selectively stimulates stromal cell proliferation and gives rise to an overgrowth of these cells at the cost of the initially appearing epithelial cells. As determined by immunocytochemical analysis of keratins in cytospins, such stromal cell outgrowths contained less than $5 \%$ epithelial cells during the first passage. Usually this low number of contaminating epithelial cells decreased even further in subsequent subcultures (Fig. 3). In fact, epithelial cells were not detected by microscopy or cytokeratin staining after the second passage. Needless to say, the epithelial cell content of the first harvest depends on the time spent waiting for the stromal cells to crowd out the epithelial cells (see also Fig. 2). Since trypsinization and subcultivation in our hands appeared to be selective in favor of the stromal cell population, subcultures were usually initiated at an early stage.

Mesenchymal cells are known to express vimentin as intermediate-sized filament protein [18-22]. However, it was shown by others that nonmesenchymal cells can also express vimentin in vitro culture [31]. Since we experienced this to be true for our primary 
cultures of prostatic epithelium (PA 555: $98 \%$ keratinpositive as well as $95 \%$ vimentin-positive cells), the results obtained with anti-vimentin antibodies are of limited value for the characterization of cultured prostatic (stromal) cells.

Fibroblastic cells, though traditionally considered to have a relatively common morphology in culture, are endowed with multiple functional properties; they play an essential role in the synthesis and regulation of extracellular matrix components, contribute to wound healing, and are involved in the pathogenesis of fibrotic processes [32] and probably in neoplasia [33]. Characterization of intermediate filament proteins and contractile proteins has shown to be a useful approach in differentiating fibroblastic phenotypes [23,34]. Defined subtypes have been found to express both vimentin and desmin, suggesting that some stromal cells are equipped with muscular elements and might participate in wound closure and visceral contraction $[35,36]$. For example, immunohistochemical studies have revealed that some testicular stromal cells have muscular phenotypic features, supporting the assumption that these myoid cells might influence the migration of sperm [35]. Recently, a remarkable morphological and functional similarity was demonstrated between these rat testes-derived peritubular cells, and rat prostatic stromal cells in culture [7]. Furthermore, the determination of cytoskeletal proteins in stromal cells associated with pathologic conditions has revealed a spectrum of phenotypes that have not yet been found in normal tissues [37]. On one hand, these findings support the possibility that certain epithelial neoplasias affect the growth and differentiation of fibroblasts present in their immediate vicinity. Fibroblasts associated with lung, breast, and colon carcinomas, for example, have been shown to express $\alpha-S M$ actin [24]. These tumor-associated myofibroblasts are thought to be responsible for the desmoplastic response to neoplasias $[24,38]$. On the other hand, desmoplasia has been considered to arise in early stages of tumorigenesis [24]. This led to the search for mesenchymal cells with smooth muscle cell differentiation features in relation to epithelial proliferations, thought to predispose to malignant transformation. Cytoskeletal analysis of specimens from colon, breast, and uterus, indeed, has revealed that the presence of $\alpha$-SM actin-expressing mesenchymal cells may be a feature of premalignant lesions or intraepithelial neoplasia [37]. A prominent role of the stroma in the pathogenesis of BPH nodules in the human prostate was proposed by McNeal more than a decade ago [39]. Obviously, the immunocytochemical observations reported here carry great potential diagnostic and prognostic significance: If similar changes were to be reflected in vitro, this would provide us with a potential tool for studying these (pathologic) phenotypes in detail.

When we focus on our results regarding the initial outgrowth of the explants, a striking difference is noticed between cultures derived from $\mathrm{BPH}$ and prostatic carcinoma. Whereas BPH-derived stromal cell cultures predominantly consisted of fibroblastic cells, stromal cells derived from malignant lesions showed smooth muscle differentiation, as was clearly demonstrated by the presence of smooth muscle $\alpha$-actin protein in approximately $75 \%$ of the cells (Fig. 2). This conclusion was further substantiated by the observation that these cultures also contained relatively high numbers of desmin-positive cells (25\%) compared to $\mathrm{BPH}$-derived cultures $(<5 \%)$. The observation that a substantially lower number of cells stained for desmin than for $\alpha$-SM actin is in agreement with findings reported by Shapiro et al. [40]. These authors showed that the percent area density of actin-positive tissue in prostate biopsies was twice as large as the area density of the anti-desmin-stained tissue compartment, which led to the authors' conclusion that anti-desmin appears to underestimate the amount of prostate smooth muscle.

Immunocytochemical evaluation of serial passages revealed that in $\mathrm{BPH}$-derived cultures, increasing numbers of cells stained positive for $\alpha-S M$ actin, whereas some of the carcinoma-derived cells became $\alpha-S M$ actin negative, resulting in a more even distribution of phenotypic markers in both culture types (Fig. 3). One carcinoma-derived culture, however, retained a high level of $\alpha$-SM actin expression during all seven passages tested. The pathological classification of the parental tumor did not provide any clues as to why these cells were able to maintain this highly differentiated state under circumstances in which most cell types show a tendency to dedifferentiate to a state bearing more general mesenchymal properties [41]. The shift in phenotype observed in our experiments might be due to the separation of stromal cells from the epithelium (which was still present inside the tissue explants) as a result of subculture. However, it is also possible that the changes observed were caused by extended cultivation, as has been described by several authors $[19,42,43]$. On one hand, it has been shown that $\alpha$-SM actin-negative fibroblasts from breast tissue undergo smooth muscle differentiation after 4 days of cultivation [38]. On the other hand, vascular smooth muscle cells were shown to downregulate $\alpha$-SM actin and thereby resemble myofibroblasts [44], as might have been the case in our cultures. It is therefore important to take into consideration in future in vitro studies that apparent fibroblasts may represent modulated smooth muscle cells 
[44]. In this respect it is interesting that cultured lens cells gradually develop $\alpha$-SM actin, despite the fact that they do not contain this protein in vivo [24]. However, as the difference in phenotypes between $\mathrm{BPH}$ and carcinoma-derived cultures may gradually fade at subculture, it should be recommended to carry out (coculture) experiments with stromal cells from the earliest passage possible.

In conclusion, cultured human prostatic stromal cells are heterogeneous with regard to their differentiation markers. Two contrasting phenotypes, one exhibiting fibroblastic features and the other showing varying degrees of smooth muscle differentiation, were detected in primary cultures derived from lesions with clinically different behavior. The outgrowth of different cell populations under similar culture conditions is indicative of a remarkable divergence in the stromal-epithelial relationship between these two pathological conditions and may provide us with an excellent tool for studying these processes. The reciprocal interaction of these stromal cells with normal epithelium, for instance, tested in coculture experiments, might help us unravel the complex mechanisms leading to benign and malignant neoplasia.

\section{ACKNOWLEDGMENTS}

The authors would like to thank the Urological Research Foundation (SUWO) Rotterdam for its support.

\section{REFERENCES}

1. Cunha GR, Donjacour AA, Cooke PS, Mee S, Bigsby RM, Higgins SJ, Sugimura Y: The endocrinology and developmental biology of the prostate. Endocr Rev 8:338-362, 1987.

2. Cunha GR, Bigsby RM, Cooke PS, Sugimura Y: Stromal-epithelial interactions in adult organs. Cell Differ 17:137-148, 1985.

3. McKeehan WL, Adams PS, Rosser MP: Direct mitogenic effects of insulin, epidermal growth factor, glucocorticoid, cholera toxin, unknown pituitary factors and possibly prolactin, but not androgen, on normal rat prostate epithelial cells in serum-free, primary cell culture. Cancer Res 44:1998-2010, 1984.

4. Chang SM, Chung LW: Interaction between prostatic fibroblast and epithelial cells in culture: Role of androgen. Endocrinology 125:2719-2727, 1989.

5. Orlowski J, Clark AF: Estrogen metabolism by primary cultures of rat ventral prostate epithelial and stromal cells. J Steroid Biochem 29:361-368, 1988.

6. Taketa S, Nishi N, Takasuga H, Okutani T, Takenaka I, Wada F: Differences in growth requirements between epithelial and stromal cells derived from rat ventral prostate in serum-free primary culture. Prostate 17:207$218,1990$.

7. Swinnen K, Deboel L, Cailleau J, Heyns W, Verhoeven $\mathrm{G}$ : Morphological and functional similarities between cultured prostatic stromal cells and testicular peritubular myoid cells. Prostate 19:99-112, 1991.

8. Horoszewicz JS, Leong SS, Kawinski E, Karr JP, Rosenthal H, Ming Chu T, Mirand EA, Murphy GP: LNCaP model of human prostatic carcinoma. Cancer Res 48:1809-1810, 1983.

9. Kaighn ME, Narayan KS, Ohnuki Y, Lechner JF, Jones LW: Establishment and characterization of a human prostatic carcinoma cell line (PC-3). Invest Urol 17:1623, 1979.

10. Stone KR, Mickey DD, Wunderli H, Mickey GH, Paulson DF: Isolation of a human prostatic carcinoma cell line (DU 145). Int J Cancer 21:274-281, 1978.

11. Loop SM, Rozanski TA, Ostenson RC: Human primary prostate tumor cell line, ALVA-31: New model for studying hormonal regulation of prostate tumor cell growth. Prostate 22:93-108, 1993.

12. Peehl DM, Stamey TA: Serum-free growth of adult human prostatic epithelial cells. In Vitro Cell Dev Biol 22:82-90, 1986.

13. Peehl DM, Wong ST, Stamey TA: Clonal growth characteristics of adult human prostatic epithelial cells. In Vitro Cell Dev Biol 24:530-536, 1988.

14. Chaproniere DM, McKeehan WL: Serial culture of single adult human prostatic epithelial cells in serum-free medium containing low calcium and a new growth factor from bovine brain. Cancer Res 46:819-24, 1986.

15. Peehl DM, Stamey TA: Serial propagation of adult human prostatic epithelial cells with cholera toxin. In Vitro 20:981-986, 1984.

16. Merchant DJ: Primary explant culture of human prostate tissue: A model for the study of prostate physiology and pathology. Prostate 16:103-26, 1990.

17. Ramaekers F, Huysmans A, Moesker O, Kant A, Jap P, Herman C, Vooijs P: Monoclonal antibody to keratin filaments, specific for glandular epithelia and their tumors. Use in surgical pathology. Lab Invest 49:353-361, 1983.

18. Cooper D, Schermer A, Sun TT: Classification of human epithelia and their neoplasms using monoclonal antibodies to keratins: Strategies, applications, and limitations. Lab Invest 52:243-256, 1985.

19. Moll R, Franke WW, Schiller DL, Geiger B, Krepler R: The catalog of human cytokeratins: Patterns of expression in normal epithelia, tumors and cultured cells. Cell 31:11-24, 1982.

20. Osborn M, Weber K: Tumor diagnosis by intermediate filament typing: A novel tool for surgical pathology. Lab Invest 48:372-394, 1983.

21. Ramaekers FC, Puts JJ, Moesker O, Kant A, Huysmans A, Haag D, Jap PH, Herman CJ, Vooijs GP: Antibodies to intermediate filament proteins in the immunohistochemical identification of human tumours: An overview. Histochem J 15:691-713, 1983.

22. Osborn M, Geisler N, Shaw G, Sharp G, Weber K: Intermediate filaments. Cold Spring Harb Symp Quant Biol 46:413-429, 1982.

23. Skalli O, Ropraz P, Trzeciak A, Benzonana G, Gillessen D, Gabbiani G: A monoclonal antibody against alphasmooth muscle actin: A new probe for smooth muscle differentiation. J Cell Biol 103:2787-2796, 1987.

24. Sappino AP, Schurch W, Gabbiani G: Differentiation repertoire of fibroblastic cells: Expression of cytoskeletal proteins as marker of phenotypic modulations. Lab Invest 63:144-161, 1990. 
25. Seemayer TA, Schurch W, Lagace R: Myofibroblasts in human pathology. Hum Pathol 12:491-492, 1981.

26. Angus B, Purvis J, Stock D, Westley BR, Samson AC, Routledge EG, Carpenter FH, Horne CH: NCL-5D3: A new monoclonal antibody recognizing low molecular weight cytokeratins effective for immunohistochemistry using fixed paraffin-embedded tissue. J Pathol 153: 377-384, 1987

27. Ramaekers FC, Verhagen AP, Isaacs JT, Feitz WF, Moesker O, Schaart G, Schalken JA, Vooijs GP: Intermediate filament expression and the progression of prostatic cancer as studied in the Dunning $R-3327$ rat prostatic carcinoma system. Prostate 14:323-339, 1989.

28. Zondervan PE, Kwast van der ThH, Jong de A, Visser WJ, Bruijn de WC: Lysosomal localization of secretory prostatic acid phosphatase in human hyperplastic prostate epithelium. Urol Res 14:331-335, 1986.

29. Ruizeveld de Winter JA, Trapman J, Vermey M, Mulder $\mathrm{E}$, Zegers ND, van der Kwast ThH: Androgen receptor expression in human tissues: An immunohistochemical study. J Histochem Cytochem 39:927-936, 1991.

30. Henzen Logmans SC, Mullink H, Ramaekers FC, Tadema T, Meijer CJ: Expression of cytokeratins and vimentin in epithelial cells of normal and pathologic thyroid tissue. Virchows Arch 410:347-354, 1987.

31. Ben-Ze'ev A: Differential control of cytokeratins and vimantin synthesis by cell-cell contact and cell spreading in cultured epithelial cells. J Cell Biol 00:1424-1433, 1984.

32. Hasegawa T, Hirose T, Kudo E, Abe J, Hizawa K: Cytoskeletal characteristics of myofibroblasts in benign neoplastic and reactive fibroblastic lesions. Virchows Arch [A] 416:375-382, 1990.

33. Kooistra A: Stromal-epithelial interactions in the prostate and its relation to steroid hormones. In Berns PMJJ, Romijn JC, Schöder FH (eds): "Mechanisms of Progression to Hormone-Independent Growth of Breast and Prostatic Cancer." Park Ridge, NJ and Carnford UK: Parthenon Publishing Group, 1991, pp 29-54.

34. Skalli O, Schurch W, Seemayer T, Lagace R, Montan- don D, Pittet B, Gabbiani G: Myofibroblasts from diverse pathologic settings are heterogeneous in their content of actin isoforms and intermediate filament proteins. Lab Invest 60:275-285, 1989.

35. Tung PS, Fritz IB: Characterization of rat testicular peritubular myoid cells in culture: Alpha-smooth muscle isoactin is a specific differentiation marker. Biol Reprod 42:351-365, 1990.

36. Gabbiani G: The biology of the myofibroblast. Kidney Int 41:530-532, 1992.

37. Schmitt-Graff A, Gabbiani G: Phenotypic features of stromal cells in normal, premalignant and malignant conditions. Eur J Cancer 28A:1916-1920, 1992.

38. Ronnov-Jessen L, van Deurs B, Celis JE, Petersen OW: Smooth muscle differentiation in cultured human breast gland stromal cells. Lab Invest 63:532-543, 1990.

39. McNeal JE: Origin and evolution of benign prostatic enlargement. Invest Urol 15:340-345, 1978.

40. Shapiro E, Hartanto V, Lepor H: Anti-desmin vs. antiactin for quantifying the area density of prostate smooth muscle. Prostate 20:259-267, 1992.

41. Ricciardelli C, Horsfall DJ, Skinner JM, Henderson DW, Marshall VR, Tilley WD: Development and characterization of primary cultures of smooth muscle cells from the fibromuscular stroma of the guinea pig prostate. In Vitro Cell Dev Biol 25:1016-1024, 1989.

42. Franke WW, Schmid E, Schiller DL, Winter S, Jarasch ED, Moll R, Denk H, Jackson BW, Illmensee K: Differentiation-related patterns of expression of proteins of intermediate-size filaments in tissues and cultured cells. Cold Spring Harb Symp Quant Biol 46:431-453, 1982.

43. Ronnov-Jessen L, Van Deurs B, Nielsen M, Petersen OW: Identification, paracrine generation, and possible function of human breast carcinoma myofibroblasts in culture. In Vitro Cell Dev Biol 28A:273-283, 1992.

44. Petersen OW, Van Deurs B: Distinction between vascular smooth muscle cells and myoepithelial cells in primary monolayer cultures of human breast tissue. In Vitro Cell Dev Biol 25:259-266, 1989. 